\title{
AKAD BAKU PADA PEMBIAYAAN MURABAHAH DI BANK SYARIAH
}

\author{
Trisadini Prasastinah Usanti \\ Fakultas Hukum Universitas Airlangga Surabaya \\ e-mail: aditris@ymail.com
}

\begin{abstract}
ABSTRAK
Pemberlakuan kontrak baku memang sudah menjadi suatu keniscayaan bisnis yang dapat diterima keberadaannya oleh masyarakat dengan segala kelebihan dan kekurangannya. Istilah kontrak baku berasal dari terjemahan dari bahasa Inggris, yaitu standard contract. Kontrak baku merupakan perjanjian yang telah ditentukan dan dituangkan dalam bentuk formulir. Penggunaan kontrak baku adalah perwujudan dari efisiensi bisnis oleh para pelaku usaha. Dalam praktik perbankan syariah, pembiayaan murabahah dituangkan dalam bentuk akad baku, bahwa nasabah penerima fasilitas pembiayaan tidak diberikan kesempatan untuk bernegosiasi tentang klausula yang ada dalam akad pembiayaan murabahah. Adanya klausula baku pada pembiayaan murabahah di bank syariah tidaklah bertentangan dengan prinsip syariah. Kontrak baku pada pembiayaan murabahah di beberapa bank syariah telah memuat klasula yang sesuai dengan karakteristik dari pembiayaan murabahah tersebut dan telah memuat syarat minimum yang harus ada dalam akad sebagaimana ditentukan dalam Fatwa Dewan Syariah Nasional yang dirumuskan dalam Peraturan Bank Indonesia.
\end{abstract}

Kata Kunci: kontrak baku, murabahah, bank syariah.

\begin{abstract}
The implementation of standard contract has become a business necessity which is acceptable by the community with all its pros and cons. Terms of kontrak baku is derived from the translation of Standard Contract in English language. Standard contract is an agreement which has been determined and manifested in a form. The use of standard contract is a manifestation of the businessman's business efficiency. In the practice of Islamic banking, murabahah financing contract set forth in the form of raw materials, the customer who received the financing facilities would not be given the opportunity to negotiate the murabahah financing contract substations. The existence of standard contract in murabahah financing in Islamic banks is not contrary to Islamic principles. The substance of standard contract in murabahah financing in some Islamic banks has loaded articles that match with the characteristics of murabahah financing and has also contained minimum requirements that must be present in the contract as specified in the Fatwa of National Sharia Council which are formulated in Bank Indonesia Regulation.
\end{abstract}

Keywords: standard contract, murabahah, Islamic bank.

\section{PENDAHULUAN}

Bank syariah sebagaimana juga halnya dengan bank konvensional berfungsi juga sebagai lembaga intermediasi (Intermediary institution), yang mana yaitu berfungsi menghimpun dana dari masyarakat dan menyalurkan kembali dana-dana tersebut kepada masyarakat yang membutuhkannya dalam bentuk pembiayaan sebagaimana diamanatkan pada Pasal 4 ayat 1 Undang-Undang No. 21 Tahun 2008 tentang Perbankan Syariah (yang selanjutnya disingkat UU Perbankan Syariah). Pembiayaan yang disalurkan oleh bank syariah merupakan sebagian besar aset bagi bank syariah, sehingga dalam menyalurkan dananya kepada masyarakat bank syariah harus memperhatikan prinsip kehati-hatian. Istilah pembiayaan menurut Pasal 1 angka 12 Undang-Undang No. 7 Tahun 1992 tentang Perbankan sebagaimana telah diubah dengan UndangUndang No. 10 Tahun 1998 selanjutnya disingkat UU Perbankan adalah penyediaan uang atau tagihan yang dipersamakan dengan itu berdasarkan kesepakatan antara bank dengan pihak lain yang mewajibkan pihak yang dibiayai untuk mengembalikan uang atau tagihan tersebut setelah jangka waktu tertentu dengan imbalan atau bagi hasil. Sedangkan Pembiayaan menurut Pasal 1 angka 25 UU Perbankan Syariah itu adalah 
penyediaan dana atau tagihan yang dipersamakan dengan itu berupa: Transaksi bagi hasil di dalam bentuk Mudharabah dan Musyarakah; Transaksi sewa-menyewa dalam bentuk ijarah atau sewabeli dalam bentuk ijarah muntahiyah bit tamlik; Transaksi jual-beli dalam bentuk piutang Murabahah, Salam dan Istishna; Transaksi pinjam-meminjam dalam bentuk piutang Qardh; dan Transaksi sewa menyewa jasa dalam bentuk Ijarah untuk transaksi multijasa.

Berdasarkan persetujuan atau kesepakatan antara bank syariah dan/atau UUS dan juga pihak lain yang mewajibkan pihak yang dibiayai dan/atau akan diberi fasilitas dana untuk mengembalikan dana tersebut setelah jangka waktu tertentu dengan imbalan ujrah, tanpa imbalan atau bagi hasil.

Setiap transaksi yang dilakukan oleh bank syariah diwujudkan dalam bentuk tertulis, yaitu akad. Akad yang dibuat antara bank syariah dengan nasabah dituangkan dalam bentuk akad baku, sebagaimana halnya dilakukan oleh bank konvensional. Kontrak baku dalam dunia bisnis dalam praktiknya tidak hanya dilakukan dalam transaksi konvensional tetapi juga banyak dilakukan dalam transaksi yang berlandaskan pada prinsip syariah oleh lembaga keuangan bank ataupun lembaga non-bank. Hal ini menunjukkan bahwa keberlakuan kontrak baku memang sudah menjadi suatu keniscayaan bisnis yang mana dapat diterima keberadaannya oleh masyarakat dengan segala kelebihan dan kekurangannya. Penggunaan kontrak baku sebagai wujud efisiensi bisnis oleh para pelaku usaha terutama pihak yang memiliki posisi dominan dalam melakukan transaksi ternyata juga dipakai untuk memperoleh keuntungan atau benefits dengan cara mencantumkan klausula eksemsi yang mana memberatkan salah satu pihak (Alamsyah, http: //www.badilag.net/data/artikel, diunduh pada Minggu, 5 Agustus 2012, jam 10.15 WIB).

Tidak terkecuali di dalam praktik dari perbankan syariah, pembiayaan murabahah dituangkan dalam bentuk suatu akad baku, bahwa nasabah penerima fasilitas pembiayaan tidak diberikan kesempatan untuk bernegosiasi tentang klasula yang ada dalam akad pembiayaan murabahah. Salah satu skim fiqh yang mana paling popular digunakan oleh perbankan syariah adalah skim jual-beli murabahah. Transaksi murabahah ini lazim dilakukan oleh Rasulullulah SAW dan juga para sahabatnya. Secara sederhana, murabahah berarti suatu penjualan barang seharga barang tersebut ditambah keuntungan yang disepakati. Dalam definisinya disebut adanya keuntungan yang disepakati, karakteristik murabahah adalah si penjual harus memberi tahu pembeli tentang harga pembelian barang dan menyatakan jumlah keuntungan yang ditambahkan pada biaya tersebut (Adiwarman Karim, 2007:113). Berdasarkan dari penjabaran uraian di atas maka yang akan dikaji adalah akad baku pada pembiayaan murabahah.

\section{PEMBAHASAN}

Hubungan hukum bank syariah dengan nasabah penerima fasilitas pembiayaan tidaklah hanya sematamata didasarkan pada hubungan kreditor dengan debitor sebagaimana pada bank konvensional tetapi didasarkan pada berbagai macam hubungan hukum antara bank syariah dengan nasabah. Akad yang mana melandasi hubungan hukum antara nasabah dengan bank syariah dituangkan dalam bentuk akad.

Secara etimologis perjanjian dalam bahasa Arab diistilahkan dengan Mu'ahadah Ittfa, atau Akad. Dalam bahasa Indonesia dikenal dengan kontrak, perjanjian atau persetujuan yang artinya adalah suatu perbuatan dimana seseorang atau lebih mengikatkan dirinya terhadap seseorang lain atau lebih (Abdul Ghofur Anshori, 2006:19). Padanan kata perjanjian dalam bahasa Arab ialah aqad. Dalam istilah fiqih secara umum akad berarti sesuatu yang menjadi tekad seseorang untuk melaksanakan, baik yang muncul dari satu pihak seperti wakaf, talak, dan sumpah, maupun yang muncul dari dua pihak seperti jual-beli, sewa, wakalah dan juga gadai (Ascarya, 2007:35). Dengan demikian maka dapat disimpulkan bahwa akad adalah perjanjian yang menimbulkan kewajiban berprestasi pada salah satu pihak, dan hak bagi pihak lain atas prestasi tersebut, dengan ataupun tanpa melakukan kontraprestasi (Abdul Ghofur Anshori, 2006:21). Secara khusus Aqad, yaitu suatu perekatan antara ijab dan kabul dengan cara yang dibenarkan syariah yang berakibat adanya akibat hukum pada objeknya. Ijab adalah pernyataan pihak pertama mengenai isi perikatan yang diinginkan, sedangkan kabul adalah pernyataan pihak kedua untuk menerimanya. Suatu akad atau perjanjian dalam Hukum Islam adalah sah apabila memenuhi rukun dan syarat-syarat. Rukun adalah sesuatu yang harus ada dalam kontrak. Sedang syarat adalah persyaratan yang harus dipenuhi oleh rukun-rukun tersebut.

Kontrak atau perjanjian pada dasarnya dibuat berlandaskan pada asas kebebasan berkontrak di antara dua pihak yang memiliki kedudukan seimbang dan kedua pihak berusaha mencapai kata sepakat melalui proses negosiasi. Dalam perkembangannya, banyak perjanjian dalam transaksi bisnis bukan terjadi melalui negosiasi yang seimbang di antara para pihak. Salah satu pihak telah menyiapkan syarat-syarat baku 
pada formulir perjanjian yang sudah ada kemudian disodorkan kepada pihak lain untuk disetujui dengan hampir tidak memberikan kebebasan sama sekali kepada pihak lainnya untuk melakukan negosiasi atas suatu syarat-syarat yang disodorkan. Perjanjian yang demikian disebut sebagai perjanjian baku atau perjanjian standar atau juga perjanjian adhesi (Sutan Remy Sjadeini,1999:65). Kata baku atau standar artinya tolok ukur yang dipakai sebagai patokan atau pedoman bagi setiap konsumen yang menandakan hubungan hukum dengan pengusaha, yang dibakukan dalam perjanjian baku meliputi model, rumusan dan ukuran (Abdul Kadir Muhammad, 1992:6)

Penuangan akad di dalam kontrak baku sebagai perwujudan dari asas kebebasan berkontrak. Ruang lingkup kebebasan berkontrak dapat berupa kebebasan (Trisadini Prasastinah Usanti, 2012:68): Menentukan objek perjanjian; Menentukan bentuk perjanjiannnya; mengajukan syarat-syarat dalam merumuskan hak dan kewajiban; Menentukan pihak yang bertransaksi; Menentukan suatu cara penyelesaian apabila terjadi perselisihan atau sengketa.

Menurut Hasanuddin Rahman, kontrak baku itu adalah kontrak yang telah dibuat secara baku atau form standard, atau juga dicetak dalam jumlah yang banyak dengan blangko untuk beberapa bagian yang menjadi objek transaksi, seperti besarnya nilai transaksi, jenis, dan jumlah barang ditransaksikan dan sebagainya sehingga tidak membuka kesempatan kepada pihak lain untuk melakukan negosiasi mengenai apa yang akan disepakati untuk dituangkan dalam kontrak (Hasanuddin Rahman, 2003:197).

Di dalam Undang-Undang No. 8 Tahun 1999 tentang Perlindungan Konsumen (yang selanjutnya disebut UUPK) tidak merumuskan tentang perjanjian baku tetapi merumuskan mengenai klausula baku sebagaimana diatur pada Pasal 1 angka 10 bahwa klausula baku adalah setiap aturan atau ketentuan dan syarat-syarat yang telah dipersiapkan dan ditetapkan terlebih dahulu secara sepihak oleh pelaku usaha yang dituangkan dalam suatu dokumen dan/atau perjanjian yang mengikat dan wajib dipenuhi oleh konsumen. Lebih lanjut Pasal 18 ayat 1 UUPK menjelaskan bahwa pelaku usaha dilarang mencantumkan klausula baku di dalam perjanjian yang dibuatnya apabila: Menyatakan pengalihan tanggungjawab pelaku usaha; Menyatakan bahwa pelaku usaha berhak menolak penyerahan kembali barang yang dibeli konsumen; Menyatakan bahwa pelaku usaha berhak menolak penyerahan kembali uang yang dibayarkan atas barang dan/atau jasa yang dibeli oleh konsumen; Menyatakan pemberian kuasa dari konsumen kepada pelaku usaha baik secara langsung maupun tidak langsung untuk melakukan segala tindakan sepihak yang berkaitan dengan barang yang dibeli oleh konsumen secara angsuran; Mengatur hal pembuktian atas hilangnya kegunaan barang atau pemanfaatan jasa yang dibeli oleh konsumen; Memberi hak kepada pelaku usaha untuk mengurangi manfaat jasa atau mengurangi harta kekayaan konsumen yang menjadi obyek jualbeli jasa; Menyatakan tunduknya konsumen kepada peraturan yang mana berupa aturan baru, tambahan, lanjutan dan/atau pengubahan lanjutan yang dibuat sepihak oleh pelaku usaha dalam masa konsumen memanfaatkan jasa yang akan dibelinya; Menyatakan bahwa konsumen itu memberi kuasa kepada pelaku usaha untuk pembebanan hak tanggungan, hak gadai, atau hak jaminan terhadap barang yang dibeli oleh konsumen secara angsuran. Di dalam Pasal 18 ayat 2 UUPK, pelaku usaha dilarang untuk mencantumkan klausula baku yang mana letak atau bentuknya sulit terlihat atau tidak dapat dibaca secara jelas yang pengungkapannya sulit dimengerti.

Berdasarkan dari hasil inventarisir suatu akad pembiayaan murabahah dari beberapa bank syariah semua dibuat dalam bentuk baku di samping akad yang dibuat oleh notaris dalam bentuk otentik. Akad tersebut sudah dipersiapkan sejak awal oleh bank syariah dan nasabah tidak lagi bebas menentukan syarat-syaratnya karena term dan condition sudah disiapkan terlebih dahulu oleh bank syariah dengan format standar. Pada prinsipnya akad daripada bank syariah yang dituangkan dalam bentuk baku tidak bertentangan dengan syariah sepanjang akad tersebut memenuhi beberapa hal (Trisadini Prasastinah Usanti, 2012:72): Keabsahan akad, yaitu memenuhi rukun dan syarat akad; Tidak melanggar unsur yang dilarang menurut syariah, yaitu gharar, maysir, riba, zalim dan objek haram; Tidak melanggar prinsip perjanjian syariah antara lain prinsip kebebasan berkontrak, konsensualisme, kejujuran, itikad baik, persamaan, keseimbangan, keadilan, dan amanah.

Perjanjian jual-beli merupakan perbuatan hukum yang mempunyai konsekuensi terjadinya peralihan hak atas sesuatu barang dari pihak penjual kepada pihak pembeli, maka dengan sendirinya di dalam perbuatan hukum ini haruslah dapat dipenuhi rukun dan syarat sahnya jual-beli. Adapun yang menjadi rukun jual-beli terdiri dari (A. Shomad, 2010:162): Tentang subjeknya, adanya pihak penjual dan pihak pembeli; Tentang objeknya, adanya uang dan benda; dan Adanya lafaz.

Dalam suatu perbuatan jual-beli, ketiga rukun ini hendaklah dipenuhi, sebab andai kata salah satu 
rukun tidaklah terpenuhi, maka perbuatan tersebut tidak dapat dikategorikan sebagai perbuatan jualbeli. Berkaitan dengan subjeknya maka kedua belah pihak yang melakukan perjanjian jual-beli tersebut haruslah: berakal, dengan kehendaknya sendiri atau bukan dipaksa, keduanya tidak mubazir (boros) dan baliq. Sedangkan berkaitan dengan objek jual-beli disini adalah benda yang menjadi sebab terjadinya jual-beli. Benda yang dijadikan sebagai objek jualbeli ini haruslah memenuhi syarat-syarat sebagai berikut: Bersih barangnya. Adapun yang dimaksud adalah barang yang bukan dikualifikasikan sebagai barang najis atau barang yang digolongkan sebagai barang yang mana diharamkan; Dapat dimanfaatkan. Kemanfaatan barang tersebut sesuai dengan ketentuan hukum agama ataupun syariah; Milik orang yang melakukan akad. Bahwa orang yang telah melakukan perjanjian jual-beli atas sesuatu barang adalah pemilik sah atas barang tersebut. Dengan demikian jual-beli barang yang mana dilakukan oleh orang yang bukan pemiliknya adalah perjanjian jual-beli yang batal; Mampu untuk menyerahkannya. Bahwa pihak penjual dapat menyerahkan barang yang dijadikan sebagai obyek jual-beli sesuai dengan bentuk dan jumlah yang disepakati; Mengetahui. Apabila dalam suatu jual-beli keadaan barang, jumlah dan harganya, tidak diketahui maka perjanjian jual-beli itu tidak sah. Sebab bisa jadi perjanjian tersebut mengandung unsur penipuan; Barang yang diakadkan ada di tangan. Menyangkut perjanjian jual-beli atas sesuatu barang yang belum di tangan (tidak berada dalam penguasaan penjual) adalah dilarang (Abdul Ghofur Anshori, 2006:34).

Unsur yang dilarang menurut syariah berdasarkan Penjelasan Pasal 2 ayat 3 Peraturan Bank Indonesia No. 7/46/PBI/2005 tentang Akad Penghimpunan dan Penyaluran Dana bagi Bank yang Melaksanakan Kegiatan Usaha Berdasarkan dari Prinsip Syariah, dijelaskan hal-hal berikut ini: Gharar adalah transaksi yang mana mengandung tipuan dari salahsatu pihak sehingga pihak yang lain dirugikan; Maysir adalah transaksi yang mengandung unsur perjudian, untunguntungan, atau spekulatif yang tinggi; Riba adalah transaksi dengan pengambilan tambahan, baik dalam transaksi jual-beli maupun pinjam-meminjam secara batil atau bertentangan dengan ajaran Islam; Zalim adalah tindakan atau perbuatan yang mengakibatkan kerugian dan penderitaan pihak lain; Risywah adalah suatu tindakan suap dalam bentuk uang, fasilitas, atau lainnya yang melanggar hukum; Barang haram dan maksiat adalah barang atau fasilitas yang dilarang dimanfaatkan ataupun digunakan yang berdasarkan pada hukum Islam.
Prinsip perjanjian syariah yang melandasi setiap akad, antara lain (Trisadini Prasastinah Usanti, 2013: 110-112):

Pertama, Hurriyah at-Ta'uqud atau kebebasan berkontrak. Prinsip hurriyah at-Ta'uqud merupakan wujud dari kebebasan berkontrak. Masing-masing pihak yang akan mencapai tujuan akad mempunyai kebebasan untuk mengadakan penyusunan perjanjian atau freedom of making contract. Asas kebebasan berkontrak merupakan suatu asas yang universal sebagaimana dikutip oleh Agus Yudha Hernoko dari pendapat Sutan Remy Sjahdeni bahwa sebagai asas yang bersifat universal yang bersumber dari paham hukum, asas kebebasan berkontrak atau freedom of contract itu muncul bersamaan dengan lahirnya paham ekonomi klasik yang mengagungkan laissez faire atau persaingan bebas. Menurut Agus Yudha Hernoko bahwa asas kebebasan berkontrak adalah menempatkan para pihak yang berkontrak dalam posisi yang setara secara proposional, asas ini tidak menempatkan para pihak untuk saling berhadapan, menjatuhkan dan mematikan sebagai lawan kontrak justru sebaliknya asas ini menempatkan para pihak sebagai partner mitra kontrak pertukaran kepentingan mereka (Agus Yudha Hernoko, 2007:112).

Kedua, Al Musawah atau persamaan. Muamalah merupakan suatu ketentuan hukum yang mengatur hubungan akan sesama manusia untuk nanti dapat memenuhi suatu kebutuhan hidup. Dalam memenuhi kebutuhan hidup, Allah telah melebihkan sebagian kamu daripada sebagian yang lain dalam hal rezeki (QS. An-Nahl (16):71). Namun, hikmah yang dapat diambil dari adanya perbedaan tersebut ialah agar di antara mereka akan saling membutuhkan kerjasama (QS. Az-Zukhruf (43):32). Dengan adanya perilaku saling membutuhkan, maka setiap manusia memiliki kesamaan hak untuk dapat mengadakan perikatan. Dikatakan demikian, karena pada prinsipnya manusia adalah sama. Sedangkan yang membedakan hanya ketakwaannya. Allah swt berfirman: "Sesungguhnya orang yang paling mulia disisi Allah SWT diantara kamu ialah orang yang paling bertakwa" (QS. AlHujurat (49):13). (Burhanuddin S., 2009:43).

Ketiga, At-Tawazun atau keseimbangan. Secara faktual masing-masing pihak yang akan mengadakan kontrak yang memiliki berbagai latar belakang yang berbeda, namun hukum Islam tetap menekankan perlunya berpegang kepada prinsip keseimbangan, karena prinsip keseimbangan dalam akad terkait dengan pembagian hak dan kewajiban. Misal adanya hak untuk mendapatkan keuntungan dalam investasi, berarti harus disertai dengan kewajiban menanggung 
risiko. Ketentuan ini merujuk pada kaidah fiqh yang menyatakan: Keuntungan muncul bersama risiko dan Hasil usaha muncul bersama tanggungan yang dikeluarkan (Burhanuddin S., 2009:43).

Keempat, Al Amanah atau kepercayaan. Amanah merupakan bentuk kepercayaan yang timbul karena adanya itikad baik dari masing-masing pihak untuk mengadakan akad. Dalam hukum perjanjian syariah, terdapat bentuk akad yang bersifat amanah. Maksud amanah disini dapat diartikan sebagai kepercayaan kepada pihak lain untuk kemudian menjalin kerja sama. Dasar hukumnya ialah dari firman Allah yang menyatakan bahwa:"Sesungguhnya Allah menyuruh kamu menyampaikan amanat kepada yang berhak menerima" (QS. An-Nisa (4):58). "Maka hendaklah yang dipercayai itu menunaikan amanatnya" (QS. Al Baqarah (2):283) "Wahai orang-orang yang beriman! Janganlah kamu mengkhianati Allah dan Rasul dan (juga) janganlah kamu mengkhianati amanat yang dipercayakan kepadamu, sedang kamu mengetahui" (QS. Al Anfal (8):27). Surat Al-Anfal ini tercantum pada akad pembiayaan di perbankan syariah sebagai dasar bahwasanya hubungan antara bank syariah dan nasabah didasarkan pada amanah sehingga harus dijaga amanah tersebut.

Kelima, Al Adalah atau keadilan. Pelaksanaan dari prinsip ini dalam suatu perjanjian atau akad menuntut para pihak untuk melakukan yang benar di dalam pengungkapan suatu kehendak dan keadaan, memenuhi semua kewajibannya. Perjanjian harus senantiasa mendatangkan keuntungan yang adil dan seimbang, serta tidak boleh mendatangkan kerugian bagi salah satu pihak. Untuk itu Allah berfirman: "Hai orang-orang yang yang beriman, hendaklah kamu jadi orang-orang yang selalu menegakkan kebenaran karena Allah, menjadi saksi dengan adil. Dan janganlah sekali-kali kebencianmu terhadap suatu kaum, membuat kamu cenderung untuk akhirnya berlaku tidak adil. Berlaku adillah karena adil itu lebih dekat kepada takwa. Dan bertakwalah kepada Allah, sesungguhnya Allah Maha Mengetahui apa kamu kerjakan" (QS. Al Maidah (5):8) (Abdul Ghofur Anshori, 2006:27).

Keenam, Al Ridha atau kerelaan. Prinsip ini yang menyatakan bahwa segala transaksi yang dilakukan harus atas dasar kerelaan antara setiap pihak, harus didasarkan pada kesepakatan bebas dari para pihak dan tidak boleh ada unsur paksaan, tekanan, penipuan, dan mis-statemen. Dasar hukum adanya asas kerelaan dalam perbuatan perjanjian terdapat dalam Al-Quran surat An-Nisa ayat 29, yang artinya sebagai berikut: "Hai orang-orang yang beriman, janganlah kamu saling memakan harta dari sesamamu dengan jalan yang bathil, kecuali dengan jalan perniagaan yang berlaku dengan suka sama suka di antara kamu. Dan janganlah kamu membunuh dirimu, sesungguhnya Allah adalah Maha Penyayang kepadamu”.

Ketujuh, Ash-Shiddiq atau kejujuran. Kejujuran merupakan hal yang prinsip bagi manusia dalam segala aspek bidang kehidupan, termasuk di dalam penyusunan kontrak muamalah. Jika kejujuran tidak diamalkan dalam penyusunan kontrak, maka akan merusak keridhaannya (uyub al-ridha). Di samping itu, ketidakjujuran di dalam penyusunan perjanjian akan berakibat perselisihan di antara para pihak. Allah berfirman: "Hai orang-orang yang beriman, bertakwalah kamu kepada Allah, dan berkatalah perkataan yang benar" (QS. Al-Ahzab (33):70). Dalam haditsnya Rasulullah SAW bersabda: "Jika kamu menjual barang dagangan, maka katakanlah tidak ada penipuan" (HR. Bukhari). Berdasarkan kutipan ayat Al Quran dan juga Al Hadits tersebut, diketahui bahwa di dalam hukum kontrak syariah sangat menekankan adanya prinsip kejujuran yang hakiki, karena hanya dengan prinsip kejujuran itulah keridhaan dari para pihak yang membuat perjanjian dapat terwujud (Abdul Ghofur Anshori, 2006:46).

Kedelapan, Itikad Baik. Untuk dpapat mengadakan kontrak haruslah dilaksanakan berdasarkan itikad baik. Di dalam pandangan Islam, niat merupakan prinsip mendasar terkait dengan unsur kepercayaan sebelum dapat melakukan suatu amal perbuatan. Dalil syariah yang menjadi dasar hukum berlakunya asas itikad baik adalah hadits Nabi yang menyatakan: "Sesungguhnya amal perbuatan tergantung pada niat, dan sesungguhnya tiap-tiap orang tergantung dari apa yang diniatkannya" (HR. Bukhari). Demikian juga dalam hadits Nabi Saw: "Orang yang terbaik di antara kamu adalah orang yang paling baik dalam pembayaran akan hutangnya". (HR Bukhari) (Abdul Ghofur Anshori, 2006:46).

Murabahah merupakan salah satu akad yang mana berdasarkan prinsip jual-beli, di samping akad salam dan akad istishna. Pada Fatwa DSN No. 04/DSNMUI/IV/2000 di atur tentang ketentuan umum dan khusus dari Murabahah, yaitu:

Pertama, Ketentuan Umum Murabahah dalam Bank Syari'ah: Bank dan nasabah harus melakukan akad murabahah yang mana bebas riba; Barang yang diperjualbelikan itu tidak diharamkan oleh syari'ah Islam; Bank membiayai sebagian atau seluruh harga pembelian barang yang disepakati kualifikasinya; Bank membeli barang yang diperlukan nasabah atas nama bank sendiri, dan pembelian ini harus sah dan 
bebas riba; Bank harus menyampaikan semua hal yang berkaitan dengan pembelian, misalnya jika pembelian dilakukan secara utang; Bank kemudian menjual barang tersebut kepada nasabah (pemesan) dengan harga jual senilai harga beli plus keuntungannya. Dalam kaitan ini Bank harus memberitahu secara jujur harga pokok barang pada nasabah berikut biaya yang diperlukan; Nasabah membayar harga barang yang telah disepakati tersebut pada jangka waktu tertentu yang telah disepakati; Untuk mencegah terjadinya penyalahgunaan atau kerusakan akad tersebut, pihak bank dapat mengadakan perjanjian khusus dengan nasabah; Jika bank hendak untuk mewakilkan kepada nasabah untuk membeli barang dari pihak ketiga, akad jual-beli murabahah harus dilakukan setelah barang, secara prinsip, menjadi milik bank.

Kedua, Ketentuan Murabahah kepada Nasabah: Nasabah dapat mengajukan permohonan dan janji pembelian akan suatu barang atau aset kepada bank; Jika bank menerima permohonan tersebut, ia harus membeli terlebih dahulu aset yang dipesannya secara sah dengan pedagang; Bank kemudian menawarkan aset tersebut kepada nasabah kemudian nasabah harus menerima membelinya sesuai dengan janji yang telah disepakatinya, karena secara hukum janji tersebut mengikat kemudian keduabelah pihak harus membuat kontrak jual-beli; Dalam jual-beli ini bank dibolehkan meminta nasabah untuk membayar uang muka saat menandatangani kesepakatan awal pemesanan; Jika nasabah kemudian menolak membeli barang tersebut, biaya riil bank harus dibayar dari uang muka tersebut; Jika nilai uang muka kurang dari kerugian yang harus ditanggung oleh bank, bank dapat meminta kembali sisa kerugiannya kepada nasabah; Jika uang muka memakai kontrak 'urbun sebagai alternatif dari uang muka, maka: a. jikalau nasabah memutuskan untuk membeli barang tersebut, ia tinggal membayar sisa harga; b. jika nasabah batal membeli, uang muka menjadi milik bank maksimal sebesar kerugian yang ditanggung oleh bank akibat pembatalan tersebut; dan jika uang muka tidak mencukupi, nasabah wajib melunasi kekurangannya.

Ketiga, Jaminan di dalam Murabahah: Jaminan dalam murabahah dibolehkan, agar nasabah serius dengan pesanannya; Bank dapat meminta nasabah untuk menyediakan jaminan yang dapat dipegang.

Keempat, Utang dalam Murabahah: 1. Secara prinsip, penyelesaian utang nasabah dalam transaksi murabahah tidak ada kaitannya dengan transaksi lain yang dilakukan nasabah dengan pihak ketiga atas barang tersebut. Jika nasabah menjual kembali barang tersebut dengan keuntungan atau kerugian, ia tetap berkewajiban untuk menyelesaikan utangnya kepada bank; 2. Jikalau nasabah menjual barang tersebut sebelum masa angsuran berakhir, ia tidak wajib segera melunasi seluruh angsurannya; 3. Jika penjualan barang tersebut menyebabkan kerugian, nasabah tetap harus menyelesaikan utangnya sesuai kesepakatan awal. Ia tidaklah boleh memperlambat pembayaran angsuran atau meminta kerugian itu diperhitungkan.

Kelima, Penundaan untuk Pembayaran dalam Murabahah: Nasabah yang memiliki kemampuan tidak dibenarkan menunda penyelesaian utangnya; Jika nasabah menunda-nunda pembayaran dengan sengaja, atau jika salah satu pihak tidak menunaikan kewajibannya, maka penyelesaiannya akan dilakukan melalui Badan Arbitrasi Syari'ah setelah tidak tercapai kesepakatan melalui musyawarah.

Keenam, Bangkrut di dalam kegiatan Murabahah: Bilamana nasabah telah dinyatakan pailit dan gagal menyelesaikan utangnya, maka bank harus menunda tagihan utang sampai ia menjadi sanggup kembali, atau berdasarkan kesepakatan.

Berdasarkan penjelasan Peraturan Bank Indonesia No. 7/46/PBI/2005 tentang Akad Penghimpunan dan Penyaluran Dana Bagi Bank yang Melaksanakan Kegiatan Usaha Berdasarkan Prinsip Syariah bahwa dalam akad ada ketentuan persyaratan minimum akad tersebut disusun berpedoman kepada fatwa yang mana diterbitkan oleh instansi Dewan Syariah Nasional dengan memberikan penjelasan lebih rinci aspek teknis perbankan guna menyediakan landasan hukum yang cukup memadai bagi para pihak yang berkepentingan. Sebagaimana telah ditegaskan pada Pasal Pasal 26 UU Perbankan Syariah, bahwa: 1. Kegiatan usaha sebagaimana dimaksud dalam Pasal 19, Pasal 20, dan Pasal 21 dan/atau produk dan jasa syariah, wajib tunduk kepada Prinsip Syariah; 2. Prinsip Syariah sebagaimana dimaksud pada ayat 1 difatwakan oleh Majelis Ulama Indonesia; 3. Fatwa sebagaimana yang dimaksud pada ayat 2 dituangkan dalam Peraturan Bank Indonesia; 4. Dalam rangka penyusunan Peraturan Bank Indonesia sebagaimana dimaksud pada ayat 3, Bank Indonesia membentuk komite perbankan syariah; 5 . Ketentuan lebih lanjut mengenai tata cara dari pembentukan, keanggotaan, dan tugas komite perbankan syariah sebagaimana dimaksud pada ayat 4 diatur dengan Peraturan BI.

Oleh karena itu, akad baku di bank syariah harus memenuhi persyaratan minimum sebagaimana diatur pada Peraturan Bank Indonesia No. 7/46/PBI/2005 tentang Akad Penghimpunan dan Penyaluran Dana Bagi Bank yang mana Melaksanakan Kegiatan Usaha 
Berdasarkan Prinsip Syariah juncto Peraturan Bank Indonesia No. 9/19/PBI/2007 tentang Pelaksanaan Prinsip Syariah dalam Kegiatan Penghimpunan Dana dan juga Penyaluran Dana serta Pelayanan Jasa Bagi Bank Syariah. Pada Pasal 9 dan Pasal 10 Peraturan Bank Indonesia No. 7/46/PBI/2005 tentang Akad Penghimpunan dan juga Penyaluran Dana bagi Bank yang Melaksanakan Kegiatan Usaha Berdasarkan Prinsip Syariah, mengatur:

Pertama, Kegiatan penyaluran dana di dalam bentuk pembiayaan berdasarkan akad Murabahah berlaku persyaratan paling kurang sebagai berikut: Bank menyediakan dana pembiayaan berdasarkan perjanjian jual-beli barang; jangka waktu pembayaran harga barang oleh nasabah kepada bank ditentukan berdasarkan kesepakatan bank dan juga nasabah; Bank dapat membiayai sebagian atau juga seluruh harga pembelian barang yang mana telah disepakati kualifikasinya; dalam hal bank mewakilkan kepada nasabah (wakalah) untuk membeli barang, maka akad Murabahah harus dilakukan setelah barang secara prinsip menjadi milik bank; Bank dapat meminta nasabah untuk membayar uang muka atau urbun saat menandatangani kesepakatan awal pemesanan barang oleh nasabah; Bank dapat meminta nasabah untuk menyediakan agunan tambahan selain barang yang dibiayai bank; kesepakatan marjin harus ditentukan satu kali pada awal akad dan tidak berubah selama periode akad; Angsuran pembiayaan selama periode akad harus dilakukan secara proporsional.

Kedua, Dalam hal bank meminta nasabah untuk membayar uang muka atau juga urbun sebagaimana dimaksud pada ayat 1 huruf e maka berlaku ketentuan sebagai berikut: 1. dalam hal uang muka, jika nasabah menolak untuk membeli barang setelah membayar uang muka, maka biaya riil bank harus dibayar dari uang muka tersebut dan bank harus mengembalikan kelebihan uang muka kepada nasabah. Namun jika nilai uang muka kurang dari nilai kerugian yang harus ditanggung oleh bank, maka bank dapat meminta lagi pembayaran sisa kerugiannya kepada nasabah; 2. dalam hal urbun, jikalau nasabah batal membeli barang, maka urbun yang telah dibayarkan nasabah menjadi milik bank maksimal sebesar kerugian yang ditanggung oleh bank akibat pembatalan tersebut, dan jika urbun tidak mencukupi, nasabah wajib melunasi kekurangannya.

Dalam pembiayaan Murabahah bank dapatlah memberikan suatu potongan dari total kewajiban pembayaran hanya pada nasabah yang mana telah melakukan kewajiban pembayaran cicilannya dengan tepat waktu dan/atau nasabah yang mana mengalami penurunan kemampuan pembayaran. Besar potongan Murabahah kepada nasabah tidak boleh diperjanjikan dalam akad dan diserahkan kepada kebijakan bank (Pasal 10 UU Perbankan Syariah).

Ketentuan dari Fatwa Dewan Syariah Nasional tentang murabahah itu dituangkan dalam Peraturan Bank Indonesia khususnya pada Pasal 9 dan Pasal 10, sehingga akad baku yang dibuat oleh bank syariah minimal haruslah memuat syarat-syarat minimum sebagaimana ditentukan dalam fatwa DSN-MUI yang telah dituangkan dalam Peraturan Bank Indonesia. Beberapa contoh klausul akan akad murabahah dari beberapa bank syariah:

\section{Akad Murabahah dari Bank Syariah X}

Pertama, Pokok Perjanjian: Bank berjanji dan mengikat diri untuk menjual barang yang dipesan oleh nasabah dan menyerahkannya kepada nasabah, dan nasabah dengan ini berjanji dan mengikat diri untuk membeli dan menerima barang serta membayar harganya kepada bank.

Kedua, Barang: yang dipesan oleh pihak nasabah dengan spesifikasi sebagaimana diuraikan dalam suatu lampiran dan menjadi satu kesatuan yang tidak terpisahkan dari Akad yang diadakan oleh bank untuk dijual kepada nasabah.

Ketiga, Harga: 1. Jual-beli akan dilakukan dengan Harga Jual bank terdiri dari Harga Beli Bank dan juga Keuntungan Bank; 2. Harga jual bank telah disepakati pada saat itu dan oleh karena itu tidak dapat berubah karena sebab apapun termasuk bila terjadi perubahan kondisi moneter; 3 . Harga jual bank tidak termasuk biaya-biaya yang timbul sehubungan dengan pembuatan akad ini, seperti biaya notaris, meterai dan lain-lain sejenisnya, yang mana oleh para pihak telah disepakati dibebankan sepenuhnya kepada nasabah.

Keempat, Penyerahan Barang: 1. Berdasarkan syarat-syarat pembelian antara bank dan pemasok, maka atas persetujuan dan juga sepengetahuan bank, penyerahan barang akan dilakukan langsung oleh pemasok kepada nasabah; 2. Apabila pelaksanaan teknis pembelian barang oleh bank dari pemasok dilakukan oleh nasabah untuk dan atas nama bank berdasarkan kuasa dari bank, maka kuasa harus dibuat secara tertulis sesuai dengan ketentuan Pasal 1795 Kitab Undang-Undang Hukum Perdata; 3. Pemberian kuasa tidak mengakibatkan nasabah dapat menuntut bank untuk membatalkan akad ini atau menuntut ganti rugi jika nasabah mengetahui barang itu bukan milik bank sebagaimana dimaksud Pasal 1471 Kitab Undang-Undang Hukum Perdata. 
Kelima, Agunan: 1. Untuk dapat lebih menjamin pembayaran kembali utang murabahah dengan tertib dan secara sebagaimana mestinya oleh nasabah pada bank, maka nasabah dan/atau penjamin menjaminkan barang kepada bank berupa .... Pengikatan barang jaminan tersebut sebagai agunan akan dibuat dalam suatu akta/akad tersendiri sesuai dengan ketentuan yang berlaku; 2. Apabila menurut pendapat bank nilai dari agunan tidak lagi cukup untuk menjamin utang murabahah nasabah pada bank, maka atas permintaan pertama dari bank, nasabah wajib menambah agunan lainnya yang disetujui bank.

Keenam, Denda: 1. Dalam hal nasabah terlambat untuk membayar kewajiban dari jadual angsuran yang telah ditetapkan, maka bank akan membebankan dan nasabah setuju akan membayar denda (ta'zir) atas dasar keterlambatan tersebut; 2. Dana dari denda atas keterlambatan yang diterima oleh bank akan diperuntukkan sebagai dana sosial.

\section{Akad Murabahah dari Bank Syariah Y}

Pertama, Pembiayaan dan Penggunaannya: Bank berjanji dan dengan ini akan mengikatkan diri untuk menyediakan fasilitas pembiayaan kepada nasabah yang akan digunakan untuk membeli barang, dan nasabah berjanji serta dengan ini akan mengikatkan diri untuk menerima pembiayaan tersebut dari dan karenanya telah berutang pada bank sejumlah sebagai berikut, Harga Beli/Jumlah Utang Pokok Rp. ...... + Margin Keuntungan Rp...... = Jumlah atau Besarnya Utang Rp. ......

Kedua, Jangka Waktu dan juga Cara Pembayaran: Nasabah berjanji dan dengan ini mengikatkan diri untuk membayar kembali jumlah seluruh utangnya pada bank dalam jangka waktu sekian bulan terhitung dari tanggal akad ini ditandatangani, dengan cara mengangsur pada tiap-tiap bulan sesuai dengan jadwal angsuran yang ditetapkan dalam Surat Sanggup untuk Membayar, dan lunas pada saat jatuh tempo.

Setiap pembayaran oleh nasabah pada bank lebih dahulu digunakan untuk akhirnya melunasi biaya administrasi dan biaya lainnya berdasarkan akad ini dan sisanya barulah dihitung sebagai pembayaran angsuran/pelunasan atas harga pokok barang dan Margin Keuntungan bank. Dalam hal jatuh tempo pembayaran kembali pembiayaan jatuh bertepatan dengan bukan pada hari kerja bank, maka nasabah berjanji dan dengan ini telah mengikatkan diri untuk melakukan pembayaran pada hari pertama bank itu bekerja kembali.

Dalam hal terjadi kelambatan pembayaran oleh nasabah kepada bank, maka nasabah berjanji dan dengan ini mengikatkan diri untuk membayar biaya administrasi pada bank untuk tiap hari kelambatan, terhitung sejak saat kewajiban pembayaran tersebut jatuh tempo sampai dengan tanggal dilaksanakannya pembayaran kembali.

Ketiga, Jaminan. Untuk menjamin akan tertibnya pembayaran kembali atau pelunasan pembiayaan dan Margin Keuntungan tepat pada waktu yang telah disepakati keduabelah pihak berdasarkan akad ini, maka nasabah berjanji dan dengan ini mengikatkan diri untuk kemudian menyerahkan jaminan dan juga membuat pengikatan jaminan kepada bank sesuai dengan peraturan perundang-undangan yang berlaku, yang merupakan bagian yang tidak terpisahkan dari akad ini. Jenis barang jaminan yang diserahkan adalah berupa ....

\section{Akad Murabahah dari Bank Syariah Z}

Pertama, Harga Jual Al-Murabahah dan juga dari Penggunaannya: 1. Nasabah dengan ini berjanji dan mengikatkan diri kepada bank untuk membayar harga jual barang atau hutang murabahah, yang terdiri dari Harga Beli + Keuntungan Maksimum = Jumlah atau Harga Jual Maksimum; 2. Setiap realisasi jual-beli al-murabahah secara bertahap maupun sekaligus, dipergunakan khusus untuk pembelian.

Kedua, Jual-Beli dan Hutang Murabahah. Dengan tetap memperhatikan dan menaati ketentuan tentang jual-beli barang secara murabahah, bank berjanji dan dengan ini mengikatkan diri untuk melaksanakan jual-beli barang dengan pihak nasabah dengan cara piutang murabahah, setelah pihak nasabah memenuhi seluruh prasyarat sebagai berikut: 1 . Nasabah telah menyerahkan kepada bank seluruh dokumen nasabah, termasuk dan tidak terbatas pada dokumen-dokumen jaminan yang berkaitan dengan akad ini; 2 . nasabah telah menandatangani akad ini serta akad pengikatan jaminannya serta menyerahkan bukti-bukti tentang kepemilikan atau hak lain atas barang jaminannya; 3. Nasabah telah membuat dan juga menandatangani tanda bukti penerimaan uang, dan meyerahkannya kepada bank; Terhadap pelaksanaan jual beli secara murabahah, nasabah wajib menyerahkan aksep atau Surat Sanggup membayar kepada bank.

Ketiga, Jangka Waktu dan juga Cara Pembayaran. Nasabah berjanji dan dengan ini akan mengikatkan diri untuk membayar kembali jumlah keseluruhan kewajibannya pada bank dalam jangka waktu yang terhitung dari tanggal sekian sampai dengan tanggal sekian dengan cara mengangsur pada tiap-tiap bulan sesuai dengan jadwal angsuran yang telah ditetapkan dalam Surat Sanggup Membayar, yang merupakan 
bagian yang mana tidak terpisahkan dari akad ini: 1 . Dalam hal terjadi keterlambatan pembayaran oleh nasabah kepada bank, maka nasabah berjanji dan dengan ini mengikatkan diri untuk membayar biaya administrasi sebesar kerugian yang dialami oleh bank dengan perhitungan sejak saat kewajiban pembayaran tersebut telah jatuh tempo sampai dengan tanggal dilaksanakannya suatu pembayaran kembali; 2 . Setiap pembayaran oleh nasabah kepada bank lebih dahulu digunakan untuk melunasi biaya administrasi dan biaya lainnya berdasarkan akad ini dan sisanya baru dihitung sebagai pembayaran angsuran/pelunasan atas harga jual bank sebagai penjual; 3. Dalam hal jatuh tempo pembayaran kembali pembiayaan jatuh bertepatan dengan bukan pada hari kerja bank, maka nasabah berjanji dan dengan ini mengikatkan diri untuk melakukan pembayaran 1 (satu) hari sebelum hari yang bukan merupakan hari kerja tersebut.

Keempat, Jaminan. Untuk menjamin tertibnya pembayaran kembali atau pelunasan pembiayaan dan margin keuntungan tepat pada waktu yang telah disepakati kedua belah pihak berdasarkan akad ini, maka nasabah berjanji dan dengan ini mengikatkan diri untuk menyerahkan jaminan dan juga membuat pengikatan jaminan kepada bank sesuai ketentuan peraturan perundang-undangan yang berlaku, yang merupakan bagian yang tidak terpisahkan dari akad ini. Jenis barang jaminan yang diserahkan adalah berupa ....

Dari ketiga contoh dari akad baku pembiayaan murabahah di atas maka hal yang harus ada dalam akad murabahah, yaitu adanya klausul mengenai harga jual barang yang terdiri dari harga beli barang dan margin keuntungan yang akan diperoleh bank syariah. klausul ini merupakan karakteristik dari akad murabahah yang berdasarkan prinsip jual-beli, bahwa pembeli atau nasabah harus mengetahui berapa harga beli barang dan keuntungan yang akan diperoleh bank syariah. Adanya jaminan pada pembiayaan murabahah diperbolehkan sebagaimana di dalam Fatwa Dewan Syariah Nasional disebutkan bahwa Jaminan dalam murabahah dibolehkan, agar nasabah serius dengan pesanannya. Bank dapat untuk meminta nasabah untuk menyediakan jaminan yang dapat dipegang. Pada umumnya jaminan yang diberikan oleh nasabah adalah benda yang menjadi objek dari pembiayaan murabahah. Bila jika dikaji menurut hukum jaminan adalah diperbolehkan mengingat bahwa pembiayaan murabahah adalah didasarkan pada akad jual-beli maka objek atas pembiayaan murabahah menjadi milik dari nasabah sehingga nasabah mempunyai kewenangan dalam menjaminkan benda tersebut.
Dalam perjanjian baku itu kadangkala terdapat klausul eksemsi atau juga exemtion clause, dalam bahasa Belanda disebut dengan istilah exoneratie clausule dalam akad. Dimaksud dengan klausula eksemsi adalah suatu klausula dalam kontrak yang membebaskan atau membatasi tanggungjawab dari salah satu pihak jika terjadi wanprestasi padahal menurut hukum, tanggungjawab tersebut mestinya dapat dibebankan kepadanya (Munir Fuady, 2007: 98). Demikian juga dikemukakan oleh Sutan Remy Sjahdeini bahwa dalam perjanjian baku seringkali dimuat klausul-klausul yang sangat menekan nasabah, hal demikian bertentangan dengan asas kepatutan atau asas keadilan. Termasuk klausul-klausul yang berat sebelah adalah klausul eksemsi. Perjanjian yang berat sebelah yang mau menang sendiri di pihak bank, di masa lalu banyak dinyatakan oleh pengadilan sebagai perjanjian yang bertentangan dengan asas kepatutan dan akhirnya dinyatakan sebagai klausul yang tidak sah dan batal demi hukum (Sutan Remy Sjadeini, 1999:139). Adanya klausula eksemsi dalam akad bank syariah yangs jelas bertentangan dengan syariah disamping melanggar Pasal 18 ayat 1 UUPK huruf a, klausula eksemsi atau klausula yang menyatakan bahwa pengalihan tanggungjawab pelaku usaha yang mengakibatkan klausula akad tersebut akibatnya batal demi hukum.

\section{PENUTUP \\ Kesimpulan}

Akad baku pada pembiayaan murabahah di bank syariah tidak bertentangan dengan prinsip syariah sepanjang pada akad tersebut memenuhi keabsahan akad, yaitu dengan memenuhi rukun dan syarat akad murabahah, tidak melanggar unsur yang dilarang menurut syariah yaitu gharar, maysir, riba, zalim dan objek haram dan tidak melanggar prinsip perjanjian syariah, yaitu kebebasan berkontrak, konsensualisme, kejujuran, itikad baik, persamaan, keseimbangan, keadilan, dan amanah. Akad baku pada pembiayaan murabahah di beberapa bank syariah telah memuat klasula sesuai dengan karakteristik dari pembiayaan murabahah tersebut dan yang telah memuat syarat minimum yang harus ada dalam akad sebagaimana ditentukan dalam fatwa Dewan Syariah Nasional yang dirumuskan dalam Peraturan Bank Indonesia.

\section{Rekomendasi}

Akad baku meskipun sebenarnya telah memenuhi unsur-unsur di dalam ketentuan tentang pembuatan perbankan murabahah dan juga kerapkali dilakukan oleh pihak Bank Syariah, ada baiknya bila terdapat 
satu kesatuan hukum berupa himpunan peraturan yang unifikasi mengenai kebakuan dalam perbankan syariah ataupun bank non-syariah, agar supaya dapat menipiskan pendapat masyarakat tentang negatifnya artian dari klausula atau akad baku.

\section{DAFTAR PUSTAKA}

\section{Buku:}

Anshori, Abdul Ghofur, 2006, Pokok-Pokok Hukum Perjanjian Islam di Indonesia, Yogjakarta: Citra Media.

Ascarya, 2007, Akad dan Produk Bank Syariah, Jakarta: Raja Grafindo Persada.

Fuady, Munir, 2007, Hukum Kontrak (Dari Sudut Pandang Hukum Bisnis) Bandung: Citra Aditya.

Karim, Adiwarman, 2007, Bank Islam: Analisis Fiqih dan Keuangan, Jakarta: Raja Grafindo Persada.

Muhammad, Abdul Kadir, 1992, Perjanjian Baku dalam Praktek Perusahaan Perdagangan, Bandung: Citra Aditya Bakti.

Rahman, Hasanuddin, 2003, Contract Drafting, Bandung: Citra Aditya Bakti.

Shomad, Abd., 2010, Hukum Islam Penormaan Prinsip Syariah dalam Hukum Indonesia, Jakarta: Prenada.

Sjahdeini, Sutan Remy, 1993, Kebebasan Berkontrak dan Perlindungan yang Seimbang Bagi para Pihak dalam Perjanjian Kredit Bank di Indonesia, Jakarta: Institut Bankir Indonesia. , 1999, Perbankan Islam dan Kedudukannya dalam Tata Hukum Perbankan Indonesia, Jakarta: Pustaka Utama Grafiti.

Susanto, Burhanuddin, 2009, Hukum Kontrak Syariah, Yogjakarta: BPFE.

Usanti, Trisadini Prasastinah, 2013, Prinsip KehatiHatian Pada Transaksi Perbankan, Surabaya: Airlangga University Press.

\section{Disertasi, Hasil Penelitian:}

Hernoko, Agus Yudha, 2007, Azas Proporsionalitas dalam Kontrak Komersial, Disertasi, Pascasarjana, Unair.
Usanti, Trisadini Prasastinah, A. Shomad, Ari Kurniawan, 2012, Absorpsi Hukum Islam dalam Akad di Bank Syariah, Laporan Penelitian DIPA Universitas Airlangga, Unggulan Perguruan Tinggi.

\section{Website:}

Alamsyah, Hakim Pengadilan Agama Sengeti, Klausula Eksemsi dalam Kontrak Baku Syariah, 2 April 2012: http://www.badilag.net/data/artikel (diakses tanggal 5 Agustus 2012).

\section{Peraturan Perundang-Undangan:}

Undang-Undang Republik Indonesia No. 7 Tahun 1992 tentang Perbankan Lembaran Negara Republik Indonesia Tahun 1992 No. 31, Lembaran Negara Tahun 1992 Nomor 31, Tambahan Lembaran Negara Nomor 3472.

Undang-Undang Republik Indonesia No. 10 Tahun 1998 tentang Perubahan Undang-Undang Nomor 7 Tahun 1992 tentang Perbankan, Lembaran Negara Republik Indonesia Tahun 1998 No. 182. Tambahan Lembaran Negara No. 3790.

Undang-Undang Republik Indonesia No. 8 Tahun 1999 tentang Perlindungan Konsumen

Undang-Undang Republik Indonesia No. 21 Tahun 2008 tentang Perbankan Syariah, Lembaran Negara Republik Indonesia Tahun 2008 No. 94.

Peraturan Bank Indonesia No. 7/46/PBI/ 2005 tentang Akad Penghimpunan dan Penyaluran Dana bagi Bank yang Melaksanakan Kegiatan Usaha Berdasarkan Prinsip Syariah.

Peraturan Bank Indonesia No. 9/19/PBI/2007 tentang Pelaksanaan Prinsip Syariah dalam Kegiatan Penghimpunan Dana dan Penyaluran Dana serta Pelayanan Jasa Bank Syariah.

\section{Fatwa Dewan Syariah Nasional:}

Fatwa DSN No. 04/DSN-MUI/IV/2000 tentang Murabahah. 